\title{
The actuarial science editorship of the Accounting \& Finance Review: some general considerations
}

\author{
Luís Eduardo Afonso ${ }^{1}$ \\ (D) https://orcid.org/0000-0003-4639-8299 \\ Email: lafonso@usp.br \\ 1 Universidade de São Paulo, Faculdade de Economia, Administração e Contabilidade, Departamento de Contabilidade e Atuária, São Paulo, SP, \\ Brazil
}

Correspondence address

Luís Eduardo Afonso

Universidade de São Paulo, Faculdade de Economia, Administração e Contabilidade, Departamento de Contabilidade e Atuária

Avenida Professor Luciano Gualberto, 908 - CEP 05508-010

Cidade Universitária - São Paulo - SP - Brazil

This editorial aims to present some thoughts regarding the actuarial science editorship of the Accounting \& Finance Review (Revista Contabilidade \& Finanças - $R C \& F)$. This brief article benefits from the analysis framework provided by the research agenda developed in international journals of reference in actuarial science. It is important to have an external benchmark to better understand what we do internally.

First, it should be stressed that the field of actuarial science is quite wide. The International Actuarial Association (IAA) has six sections: Actuarial Approach for Financial Risks (AFIR-ERM), Actuarial Studies in Non-Life Insurance (ASTIN), International Actuarial Association Health Section (IAAHS), IAA Life Section (IAALS), International Association of Consulting Actuaries (IACA), and Pensions, Benefits, and Social Security Section (PBSS), as well as Actuaries Without Borders (AWB). These are quite specific areas of work. Obviously, the research in each of these areas focuses on particular objects and requires specific knowledge on the part of the academics. Thus, this text aims to provide a general outline of the area without aspiring to delve deeply into the peculiarities of specific topics.

When I assumed the post of Associate Editor of Actuarial Science, in 2015, the panorama was quite different from what it is today. The number of papers submitted was small. A large portion did not go beyond the desk stage. It is impossible to pinpoint a specific date or event, but there has been a gradual, clear, and natural change in the panorama of the actuarial science editorship. The past few years have seen quite positive developments. Expressive growth has been verified in the quantity of articles submitted. At the same time, and more importantly, the increase in quantity has been accompanied by a notable improvement in the quality of the articles submitted. More relevant research questions, a more solid theoretical foundation, a closer dialogue with the latest developments in the international literature, the increasing (and justified) use of more sophisticated techniques, and more evident contributions to the public interest are some of the elements on which the positive assessment presented is based.

Initially, we could assume that this change originated from the urgency of the topic of the pension reform in Brazil's political-economic agenda. This occurred as a result of Proposed Constitutional Amendment (Proposta de Emenda Constitucional - PEC) 287 presented by Michel Temer's government in December of 2016 and was reinforced by PEC 6, presented by President Jair Bolsonaro in February of 2019. However, of the eight actuarial science papers published from 2017 to 2019 in the RC\&F, only three deal specifically with pensions. This proportion may be understood as evidence that the research in the actuarial area in Brazil has expanded and sought to broaden its focus. 
A brieflook at these articles reveals the actuarial research panorama in Brazil and the gaps that have been explored by researchers, predominantly in the life area. In 2017, two papers were published. Beltrão and Sugahara (2017) elaborate specific mortality tables for federal government employees, a highly relevant topic for the Federal Civil Servants Pension Plan (Regime Próprio de Previdência Social - RPPS) of the Federal Government of Brazil and for the Foundation for Supplementary Civil Servant Pension Plan (Fundação de Previdência Complementar do Servidor Público - Funpresp). Chan and Marques (2017) address the topic of the regulation originating from Solvency II. Motivated by the introduction of regulatory capital by the Superintendence of Private Insurance (Superintendência de Seguros Privados - Susep), the authors study the effects on an insurance company, a private pensions company, and a special savings company.

In 2018, only one article was published. Based on the changes that would be made to the rules of the Brazilian National Pension Scheme (Regime Geral de Previdência Social - RGPS) if PEC 287/2016 had been approved, Gouveia, Souza, and Rêgo (2018) calculate the actuarially fair contribution rates for the case of the PEC and with the social security factor (fator previdenciário) rule. This is a classic study topic in the area of social security. The authors employ an actuarial model, with multiple decrements and survivor's benefits to the spouse and dependents.

In 2019, as a result of the increase in submissions mentioned before, five papers were published. Souza (in press) delves deeper into the topic of his previous study, by building dynamic actuarial models, in contrast with the static models usually employed to calculate the required contribution rates. Lima and Aquino (2019) return to the topic of social security, but with a different focus. Employing a mixed methods approach, the authors study the financial resilience of the state and local civil servants pension plans. Souza (2019) makes an interesting contribution, calculating upper and lower bounds for life annuities and whole life insurance, based on incomplete mortality data, thus expanding the work of Cohen (2011).

Also in 2019, the editorship's only two non-life papers were published. Carvalho and Carvalho (2019) employ a stochastic methodology to calculate the probability of capital insufficiency of insurers. The authors employ auto and liability insurance data to calculate incurred but not reported (IBNR) claims reserves, employing bootstrap. Finally, Peres, Maldonado, and Candido (2019) build a bridge between actuarial science and economics, estimating the demand for auto insurance and calculating market concentration indexes, which are typical in the industrial organization literature. The lack of studies in the non-life area, in particular ones that deal with reinsurance, could constitute a gap to be explored by researchers in the future.

On one hand, the current situation of the actuarial science editorship presents a much more positive picture that in the recent past and shows an encouraging outlook. On the other, it needs to be recognized that there is still a considerable way to go. The top international journals on actuarial science and correlated areas present a large variety of research objects and sophisticated techniques.

One proxy, although imperfect, for this breadth of research agenda can be seen in the award for the best articles published every year in the North American Actuarial Journal, one of the most important journals in the area. In 2015, the paper chosen was "Multistate actuarial models of functional disability" (Fong, Shao \& Sherris, 2015). This article addresses the transitions for disability and death to long-term-care (LTC) insurance, using of a generalized linear model. In 2016, the paper awarded was "Empirical evidence on the use of credit scoring for predicting insurance losses with psychosocial and biochemical explanations" (Golden, Brockett, Ai \& Kellison, 2016). This second paper introduces an innovative approach, in which the credit score of insurers is employed to improve auto insurance claims reserves. Finally, in 2017, the award went to the paper "Insurance portfolio risk retention" (Frees, 2017). In this contribution, a new statistic is presented, whose aim is to enable more adequate risk management of a property insurance portfolio. It is noted that in this list there are contributions that address the life and non-life areas and also the intersection with the area of finance.

Another example of the diversity of research lines abroad can be seen in the directives of the Society of Actuaries (SOA) in its strategic research program (Society of Actuaries, 2019). Five topics are listed that warrant mentioning: Aging and retirement, Actuarial innovation and technology, Mortality and longevity, Health care cost trends, and Catastrophe and climate. The first is, per se, a classic area of study in actuarial science. The second covers promising technologies in various areas, such as artificial intelligence, predictive modeling, machine learning, big data, autonomous vehicles, and genetic testing. Research in the area of insurance regulation and behavioral economics also forms part. The third topic concerns mortality and longevity, whose predictions are more and more important for the areas of pensions and life insurance. The fourth topic studies the area of health, with an emphasis on costs, which have been an enormous challenge for all countries. Finally, the focus on weather events and catastrophes denotes the concern 
in the actuarial community about climate change and the impact this will have on the insurance market. Extreme events will be more and more important and will affect more people, companies, and countries. They may require effective actions by governments. These should be based on appropriate reasoning and actuaries can certainly collaborate in this.

Along these lines, two topics that have still barely been explored in Brazil may represent promising research opportunities. Both share the characteristic of originating from modifications in the legal-institutional framework and being related to each other. The first is regulation of the insurance market. This topic is so important that one of the most prestigious journals in the area, The Geneva Papers on Risk and Insurance - Issues and Practice, published a special edition on regulation in 2018. As Gründl (2018) points out, besides the regulation of aspects linked to solvency, consumer protection is an equally relevant item. Both are strongly connected, given that consumer rights, defined by regulatory bodies, may affect the solvency of insurance companies. At the same time, they may positively contribute to the soundness of the financial system, given the key role of insurers and the huge amount of funds under their responsibility. One of the first studies along these lines, which analyzes the effects of adopting Pillar III of Solvency II on insurers in the European Union, is that of Gatzert and Heidinger (2019).

The second topic is the implementation of International Financial Reporting Standard (IFRS) 17, which should come into effect in 2022 for insurance companies. As is well established in the literature (Gordon, 2019; Lourenço \& Branco, 2015), the adoption of IFRS, from 2005 onward, represented a breakthrough in the accounting research, giving rise to an extensive set of studies. This topic can be considered especially worthy of attention for the actuarial science editorship of RC\&F, given that the Journal is linked to the Accounting and Actuarial Science Department of the School of Economics, Business, and Accounting of the University of São Paulo (FEA/USP), which played a leading role in the adoption of IFRS in Brazil. The complexity of IFRS 17 constitutes a major challenge for actuaries, who will come to play an even more predominant role in insurers and in auditing firms, besides requiring greater interaction with the accounting and finance areas. Pioneering studies on the impacts of this standard were conducted by Chevallier, Dal Moro, Krvavych, and Rudenko (2018) and England, Verrall, and Wüthrich (2019).

It must also be noted that the research in the actuarial area has benefited from the countless and ever faster technological changes. Marjorie Ngwenya pointed out the following in her presidential address at the Institute and Faculty of Actuaries (IFoA): "It is a time of change. Change brings about challenges, opportunities, and risks [...] Our skills give us a natural edge in this regard - an ability to understand the interaction of complex changes" (Ngwenya, 2018, p. 2, p. 5). Thus, new topics have widened the research agenda in actuarial science. Cyber risk (Egan et al., 2019; Eling, 2018) and the internet of things (with its major impact on the area of health) (Spender et al., 2019) can both be mentioned here. Similarly, not so recent techniques, such as predictive modeling, are being used more and more (again particularly in health) (Duncan, Loginov \& Ludkovski, 2016; Lally \& Hartman, 2016). Techniques such as machine learning have been used for quite traditional (and ever more relevant) topics, such as mortality forecasting models (Deprez, Shevchenko \& Wüthrich, 2017). And, finally, the expression big data has become more and more common for various sciences, and actuarial science is no exception (Zhang, 2017).

Although these frontier areas are very challenging, traditional topics still appear for researchers, outlining new paths to be explored. With some inevitable personal bias, it can be affirmed that these three areas deserve more qualified investigative efforts on the part of Brazilian researchers. Two are linked to social protection, which is so relevant in our country.

The first is social security. Population ageing, the new labor relations, and the challenge of combining adequacy and sustainability in pension systems, particularly for payas-you-go regimes, have resulted in highly relevant studies abroad. In particular, actuaries have led the research on notional defined contribution (NDC) systems. Examples worthy of note are the contributions of Pérez-Salamero González, Ventura-Marco, and Vidal-Meliá (2017) and Alonso-García, Boado-Penas, and Devolder (2018).

The second area is microinsurance. Three times in the past few years $(2014,2016$, and 2019) The Geneva Papers has published special editions addressing this subject. It is a clear indicator of its relevance and the promising research agenda. As Dror (2019) points out, there is a tendency in the insurance industry to offer products that better cater to individual needs, instead of one-size-fits-all products. This is only possible with the improvement of models that reflect the risks more adequately and with the employment of big data to provide more information. This has generated more policy-oriented and more sophisticated articles even in areas in which products with a long tradition encounter major challenges, such as that of health insurance.

The third area lies at the intersection between insurance research and behavioral economics. For a long 
time it has been known (Kahneman \& Tversky, 1979) that economic agents may not behave in accordance with the canons of expected utility theory, particularly in risky conditions. This is exactly the situation in which an economic agent demands some kind of insurance. Thus, behavioral economics can provide valuable insights for understanding aspects linked to the demand for insurance, as shown by the comprehensive surveys of Harrison and $\mathrm{Ng}$ (2019) and Richter, Ruß, and Schelling (2019).

To conclude, it is worth mentioning that high-level research in actuarial science in Brazil strongly depends on the existence of a wide community of researchers. This will only occur when more institutions offer undergraduate courses as well as masters and $\mathrm{PhD}$ programs in actuarial science and when more academics study at the top centers abroad. The exchange of ideas and greater diffusion of knowledge will provide gains for all. High skilled actuaries undoubtedly need to play a more prominent role in the formulation and analysis of public policies in the areas of pensions, health, and insurance, among others. The country has a lot to gain from such better inclusion of the actuarial community in the public debate.

\section{REFERENCES}

Alonso-García, J., Boado-Penas, M. del C., \& Devolder, P. (2018). Automatic balancing mechanisms for notional defined contribution accounts in the presence of uncertainty. Scandinavian Actuarial Journal, 2018(2), 85-108. https://doi. org/10.1080/03461238.2017.1304984

Beltrão, K. I., \& Sugahara, S. (2017). Executive branch federal civil servant mortality by sex and educational level - 1993/2014. Revista Contabilidade \& Finanças, 28(75), 445-464. https:// doi.org/10.1590/1808-057x201704320

Carvalho, B. D. R. de, \& Carvalho, J. V. de F. (2019). A stochastic approach for measuring the uncertainty of claims reserves. Revista Contabilidade \& Finanças, 30(81), 409-424. https:// doi.org/10.1590/1808-057x201907860

Chan, B. L., \& Marques, F. T. (2017). Impacts of the regulatory model for market risk capital: Application in a special savings company, an insurance company, and a pension fund. Revista Contabilidade \& Finanças, 28(75), 465-477. https://doi. org/10.1590/1808-057x201703840

Chevallier, F., Dal Moro, E., Krvavych, Y., \& Rudenko, I. (2018). Probability of sufficiency of the risk margin for life companies under IFRS 17. In Annals of the $31^{\text {st }}$ International Congress of Actuaries (p. 1-18). Berlin. Retrieved from https://ssrn.com/ abstract $=3192502$

Cohen, J. E. (2011). Life expectancy. Demographic Research, 24, 251-256. https://doi.org/10.4054/DemRes.2011.24.11

Deprez, P., Shevchenko, P. V., \& Wüthrich, M. V. (2017). Machine learning techniques for mortality modeling. European Actuarial Journal, 7(2), 337-352. https://doi.org/10.1007/ s13385-017-0152-4

Dror, D. M. (2019). Editorial. The Geneva Papers on Risk and Insurance - Issues and Practice, 44(3), 361-364. https://doi. org/10.1057/s41288-019-00131-Z

Duncan, I., Loginov, M., \& Ludkovski, M. (2016). Testing alternative regression frameworks for predictive modeling of health care costs. North American Actuarial Journal, 20(1), 6587. https://doi.org/10.1080/10920277.2015.1110491
Egan, R., Cartagena, S., Mohamed, R., Gosrani, V., Grewal, J., Acharyya, M., ... Ang, K. (2019). Cyber operational risk scenarios for insurance companies. British Actuarial Journal, 24(e6), 1-34. https://doi.org/10.1017/S1357321718000284

Eling, M. (2018). Cyber risk and cyber risk insurance: Status quo and future research. The Geneva Papers on Risk and Insurance - Issues and Practice, 43(2), 175-179. https://doi.org/10.1057/ s41288-018-0083-6

England, P. D., Verrall, R. J., \& Wüthrich, M. V. (2019). On the lifetime and one-year views of reserve risk, with application to IFRS 17 and Solvency II risk margins. Insurance: Mathematics and Economics, 85, 74-88. https://doi.org/10.1016/j. insmatheco.2018.12.002

Fong, J. H., Shao, A. W., \& Sherris, M. (2015). Multistate actuarial models of functional disability. North American Actuarial Journal, 19(1), 41-59. https://doi.org/10.1080/10920277.2014 .978025

Frees, E. (2017). Insurance portfolio risk retention. North American Actuarial Journal, 21(4), 526-551. https://doi.org/10 .1080/10920277.2017.1317272

Gatzert, N., \& Heidinger, D. (2019). An empirical analysis of market reactions to the first Solvency and Financial Condition Reports in the European insurance industry. Journal of Risk and Insurance. https://doi.org/10.1111/jori.12287

Golden, L. L., Brockett, P. L., Ai, J., \& Kellison, B. (2016). Empirical evidence on the use of credit scoring for predicting insurance losses with psycho-social and biochemical explanations. North American Actuarial Journal, 20(3), 233251. https://doi.org/10.1080/10920277.2016.1209118

Gordon, E. A. (2019). Advances and opportunities in international accounting research. Revista Contabilidade \& Finanças, 30(79), 9-13. https://doi.org/10.1590/1808057x201990290

Gouveia, A. L. L. A., Souza, F. C. de, \& Rêgo, L. C. (2018). Justiça atuarial nos cálculos previdenciários: aplicação de um modelo multidecremental para comparação da regra do fator 
previdenciário e da idade mínima. Revista Contabilidade \& Finanças, 29(78), 469-486. https://doi.org/10.1590/1808$057 \times 201805740$

Gründl, H. (2018). Editorial. The Geneva Papers on Risk and Insurance - Issues and Practice, 43(4), 591-593. https://doi. org/10.1057/s41288-018-0092-5

Harrison, G. W., \& Ng, J. M. (2019). Behavioral insurance and economic theory: A literature review. Risk Management and Insurance Review, 22(2), 133-182. https://doi.org/10.1111/ rmir.12119

Kahneman, D., \& Tversky, A. (1979). Prospect theory: An analysis of decision under risk. Econometrica, 47(2), 263-292. Retrieved from http://www.jstor.org/stable/1914185

Lally, N. R., \& Hartman, B. M. (2016). Predictive modeling in longterm care insurance. North American Actuarial Journal, 20(2), 160-183. https://doi.org/10.1080/10920277.2016.1176933

Lima, D. V. de, \& Aquino, A. C. B. de. (2019). Financial resilience of municipal civil servants' pension funds. Revista Contabilidade \& Finanças, 30(81), 425-445. https://doi. org/10.1590/1808-057x201908810

Lourenço, I. M. E. C., \& Branco, M. E. M. de A. D. C. (2015). Main consequences of IFRS adoption: Analysis of Existing literature and suggestions for further research. Revista Contabilidade \& Finanças, 26(68), 126-139. https://doi. org/10.1590/1808-057x201500090

Ngwenya, M. (2018). Address by the president of the Institute and Faculty of Actuaries Ms Marjorie Ngwenya. British Actuarial Journal, 23(e3), 1-6. https://doi.org/10.1017/ S135732171700023X

Peres, V. M., Maldonado, W. L., \& Candido, O. (2019). Automobile insurance in Brazil: Market concentration and demand. Revista Contabilidade \& Finanças, 30(81) 1-13. https://doi.org/10.1590/1808-057x201808300

Pérez-Salamero González, J. M., Ventura-Marco, M., \& Vidal-Meliá, C. (2017). A "Swedish" actuarial balance for a notional defined contribution pension scheme with disability and minimum pension benefits. International Social Security Review, 70(3), 79-104. https://doi. org/10.1111/issr.12143

Richter, A., Ruß, J., \& Schelling, S. (2019). Insurance customer behavior: Lessons from behavioral economics. Risk Management and Insurance Review, 22(2), 183-205. https:// doi.org/10.1111/rmir.12121

Society of Actuaries. (2019). SOA strategic research program. Society of Actuaries. Retrieved from https://www.soa.org/ programs/strategic-research-program/

Souza, F. C. de. (in press). Mortality dynamics and the statutory retirement age proposal: An actuarial view. Revista Contabilidade \& Finanças. https://doi.org/10.1590/1808057x201908250

Souza, F. C. de. (2019). Upper and lower bounds for annuities and life insurance from incomplete mortality data. Revista Contabilidade \& Finanças, 30(80), 282-291. https://doi. org/10.1590/1808-057x201807320

Spender, A., Bullen, C., Altmann-Richer, L., Cripps, J., Duffy, R., Falkous, C., ... Yeap, W. (2019). Wearables and the internet of things: Considerations for the life and health insurance industry. British Actuarial Journal, 24(e22), 1-31. https://doi. org/10.1017/S1357321719000072

Zhang, Y. (2017). Bayesian analysis of big data in insurance predictive modeling using distributed computing. ASTIN Bulletin, 47(3), 943-961. https://doi.org/10.1017/asb.2017.15 